Article

\title{
Trematocine, a Novel Antimicrobial Peptide from the Antarctic Fish Trematomus bernacchii: Identification and Biological Activity
}

\author{
Giulia Della Pelle ${ }^{1}{ }^{\circledR}$, Giulia Perà ${ }^{1}$, Maria Cristina Belardinelli ${ }^{1}$, Marco Gerdol ${ }^{2}{ }^{\circledR}$, \\ Martina Felli ${ }^{1}{ }^{\circledR}$, Silvia Crognale ${ }^{1}$, Giuseppe Scapigliati ${ }^{1}$, Francesca Ceccacci ${ }^{3}$, \\ Francesco Buonocore ${ }^{1, *(D)}$ and Fernando Porcelli ${ }^{1}$ (D) \\ 1 Department for Innovation in Biological, Agrofood and Forest Systems, University of Tuscia, 01100 Viterbo, \\ Italy; g.dellapelle@unitus.it (G.D.P.); giulia.p193@gmail.com (G.P.); belardinelli@unitus.it (M.C.B.); \\ martinafelli@live.it (M.F.); crognale@unitus.it (S.C.); scapigg@unitus.it (G.S.); porcelli@unitus.it (F.P.) \\ Department of Life Sciences, University of Trieste, Trieste 34128, Italy; marco.gerdol@gmail.com \\ 3 CNR - Institute for Biological Systems, Sede Secondaria di Roma-Meccanismi di Reazione, 00185 Rome, \\ Italy; francesca.ceccacci@cnr.it \\ * Correspondence: fbuono@unitus.it; Tel.: +39-761-357-644
}

Received: 20 January 2020; Accepted: 4 February 2020; Published: 6 February 2020

\begin{abstract}
Antimicrobial peptides (AMPs) are short peptides active against a wide range of pathogens and, therefore, they are considered a useful alternative to conventional antibiotics. We have identified a new AMP in a transcriptome derived from the Antarctic fish Trematomus bernacchii. This peptide, named Trematocine, has been investigated for its expression both at the basal level and after in vivo immunization with an endemic Antarctic bacterium (Psychrobacter sp. TAD1). Results agree with the expected behavior of a fish innate immune component, therefore we decided to synthesize the putative mature sequence of Trematocine to determine the structure, the interaction with biological membranes, and the biological activity. We showed that Trematocine folds into a $\alpha$-helical structure in the presence of both zwitterionic and anionic charged vesicles. We demonstrated that Trematocine has a highly specific interaction with anionic charged vesicles and that it can kill Gram-negative bacteria, possibly via a carpet like mechanism. Moreover, Trematocine showed minimum inhibitory concentration (MIC) and minimum bactericidal concentration (MBC) values against selected Gram-positive and Gram-negative bacteria similar to other AMPs isolated from Antarctic fishes. The peptide is a possible candidate for a new drug as it does not show any haemolytic or cytotoxic activity against mammalian cells at the concentration needed to kill the tested bacteria.
\end{abstract}

Keywords: antimicrobial peptides; model membranes; fish immune system; Antarctica

\section{Introduction}

Due to the dramatic increase of conventional antibiotic resistant bacterial strains, the need for new antimicrobial molecules is ever-increasing. Antimicrobial peptides [1] are a ubiquitous class of small proteins regarded as the most promising candidate to fight against antibiotic resistance. Although the presence of antibiotic peptides in bacteria has been known since gramicidine A and B were isolated in the late 1930s, the first established antimicrobial peptide from animals was mellitin, an AMP from Apis mellifera venom [2,3]. Since then, AMPs have been found in every life kingdom, also in Protista [4], Plants [5,6], and Fungi [2,7,8]. It was discovered, throughout the years, that AMPs represent a very ancient class of innate immunity effectors [9-11], despite their wide diversity in terms of structure, biosynthesis, physico-chemical characteristics, and length $[12,13]$. Usually, they are mainly classified by taking into consideration their structure ( $\alpha$-helices, $\beta$-sheets, extended or loop structures). 
Moreover, $\alpha$-helix AMPs usually show an amphipathic structure [14-16]. Their main target is the plasma membrane [1], and so far it has been proved that their selectivity relies on both their sequence and membrane charge density $[14,15,17,18]$ because bacterial cell walls show, usually, an anionic charge. AMPs are mostly able to partition into membrane bilayers, form pores, or cause perturbation of a different nature into the bilayer [19]. Despite being a promising alternative to traditional antibiotics, only a few antimicrobial peptides are currently in clinical trials [12,20]; this is due mainly to their not yet competitive costs and some regulatory issues. They have also been investigated as anti-tumor agents [21], but their best application seems to be as antimicrobial agents against multi-drug resistant microbes $[15,20,22,23]$.

Antarctica marine life is an excellent source for novel drugs due to its peculiar environment and to the specific adaptations that the species living there have evolved. Antarctic Notothenioidei have been shown to express some piscidins [24,25], a promising class of AMP, structurally related to the well-known cecropins from insects [2]. We previously isolated a piscidin peptide from the icefish Chionodraco hamatus, named Chionodracine [26], and we developed a number of mutants from its sequence $[15,27]$, which have proven to be able to effectively kill multi-drug resistant bacteria. Here, we present the isolation, membrane interaction, and antimicrobial activity of a new peptide from a red-blooded Antarctic fish, Trematomus bernacchii that we have named Trematocine.

\section{Results}

\subsection{Identification of Trematocine: A Piscidin}

The nucleotide sequence of the antimicrobial peptide Trematocine, found in the head kidney transcriptome, was confirmed by cDNA cloning with primers that amplify its entire coding region (data not shown). This sequence encodes for a pre-pro-peptide of 75 amino-acids. A multiple alignment of the amino-acid sequence of the Trematocine with other known AMP sequences from Teleosts was assembled to investigate the conserved amino acid residues (Figure 1). From the alignment, it can be evidenced that only a few amino-acids are conserved between the various species, and these amino-acids are mainly located in the N-terminal region. Moreover, with the Signal p 4.0 program, it was possible to identify the region of the signal peptide that falls between position 1 and 22 . Comparing the pro-peptide of the Trematocine to the mature peptides already identified in other Teleosts, we obtained the putative sequence of the biologically active molecule (mature peptide).

\subsection{Basal and Stimulated Expression in Different Tissues}

Trematocine mRNA basal levels have been analyzed in different organs and tissues of T. bernacchii healthy animals. The highest Trematocine expression was found in head kidney (HK) followed closely by the gills. The lowest mRNA level was found in the brain (Figure 2). The constitutive expression in organs and tissues fundamental for fish immune responses is high and, therefore, indicative of a molecule possibly involved in the innate immune system. Trematocine expression after in vivo stimulation with Psychrobacter sp. TAD1 (Figure 3), an endemic Antarctica bacterium [1], shows a significant and relevant increase after $8 \mathrm{~h}$ in both head kidney and spleen leukocytes.

\subsection{Trematocine Mature Peptide Structure}

Evaluation of the Trematocine secondary structure was carried out by circular dichroism spectroscopy, as described in Section 4.3. In buffer solution, the peptide was unstructured, as shown by the minimum found around $200 \mathrm{~nm}$. Upon addition of increasing amounts of large unilamellar vesicles (LUVs), it gradually switched to a $\alpha$-helix configuration, as revealed by the two minima at 208 $\mathrm{nm}$ and $222 \mathrm{~nm}$ (Figure 4). This happened in the presence of both anionic (PE) and zwitterionic lipid LUVs, with a significant switch at the 1:9 P/L ratio. Interestingly, there was a faint $230 \mathrm{~nm}$ minimum at the 1:2 P/L ratio, peculiar of interactions among aromatic residues [28], putatively the $\mathrm{N}$-terminal $\operatorname{Trp}$ and Phe, thus suggesting a cooperative effect among peptide monomers. The results are summarized 
in Figure 5, with the relative helical percentages (obtained via the K2D3 [29] algorithm) reported in both for zwitterionic and anionic LUVs. A slightly higher helicity is obtained in the presence of PC/PG 70:30 LUVs.
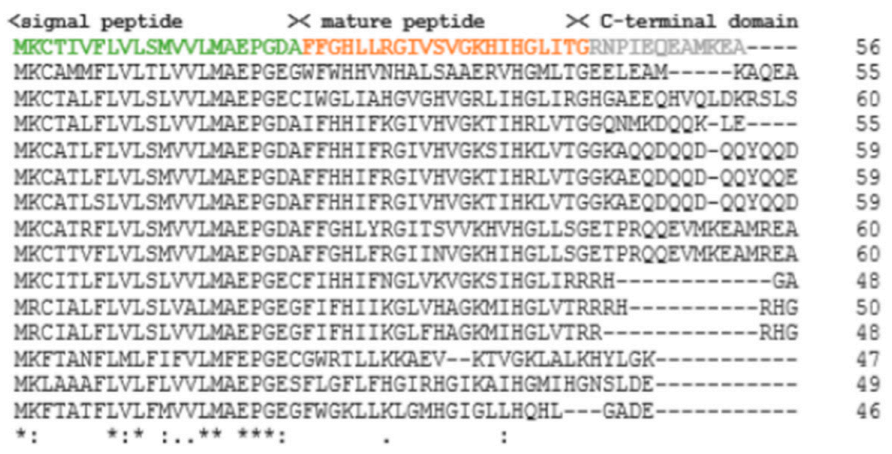

Figure 1. Multiple alignment of the predicted Trematocine amino acid sequence with other known AMP molecules from Teleost fish (accession numbers: Trematomus bernacchii, MH325166; Notothenia coriceps, XP_010772966; Larimichthys crocea, EU741827; Siniperca chuatsi, AAV65044; Dicentrarchus labrax, AAP58960; Morone saxatilis, AF385583; Morone chrysops, AAL57318; Chionodraco hamatus, FR718953; Parachaenichthys charcoti, AOW44479; Anoplopoma fimbria, ACQ58110; Epinephelus fuscoguttatus, ADE06665; Epinephelus coioides, AY705494; Hippoglossoides platessoides, AY273174; Pseudopleuronectes americanus, AY282498; and Glyptocephalus cynoglossus, AY273177).

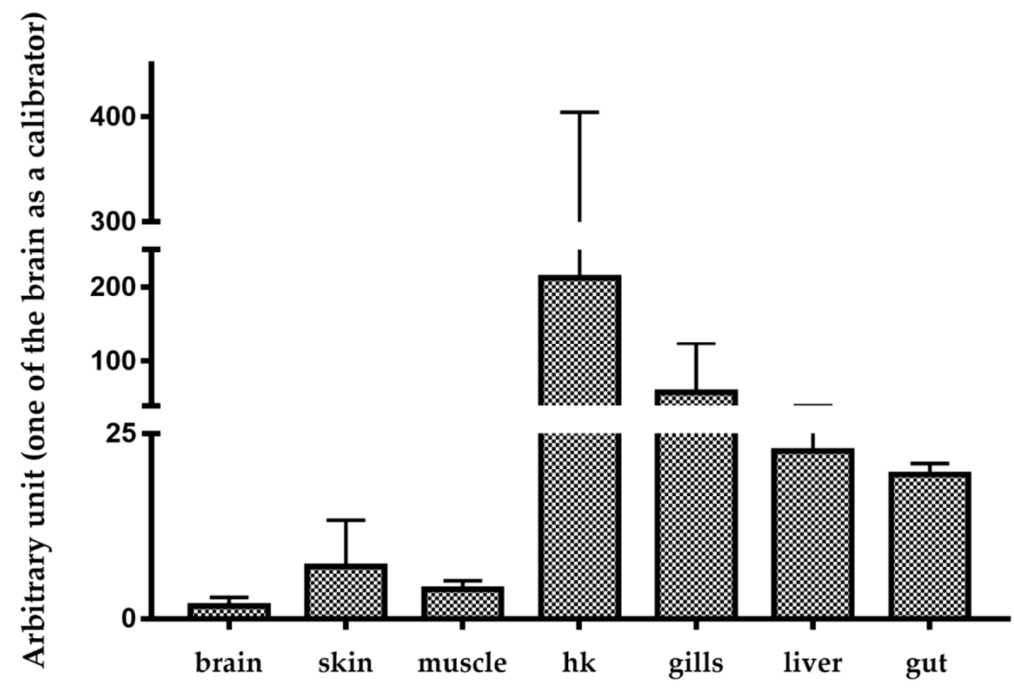

Figure 2. Trematocine basal expression in different tissues. Trematocine mRNA levels were expressed as a ratio to $18 \mathrm{~S}$ rRNA levels in the same samples after real-time PCR analysis using the tissue with the lowest expression (brain) as the calibrator. 

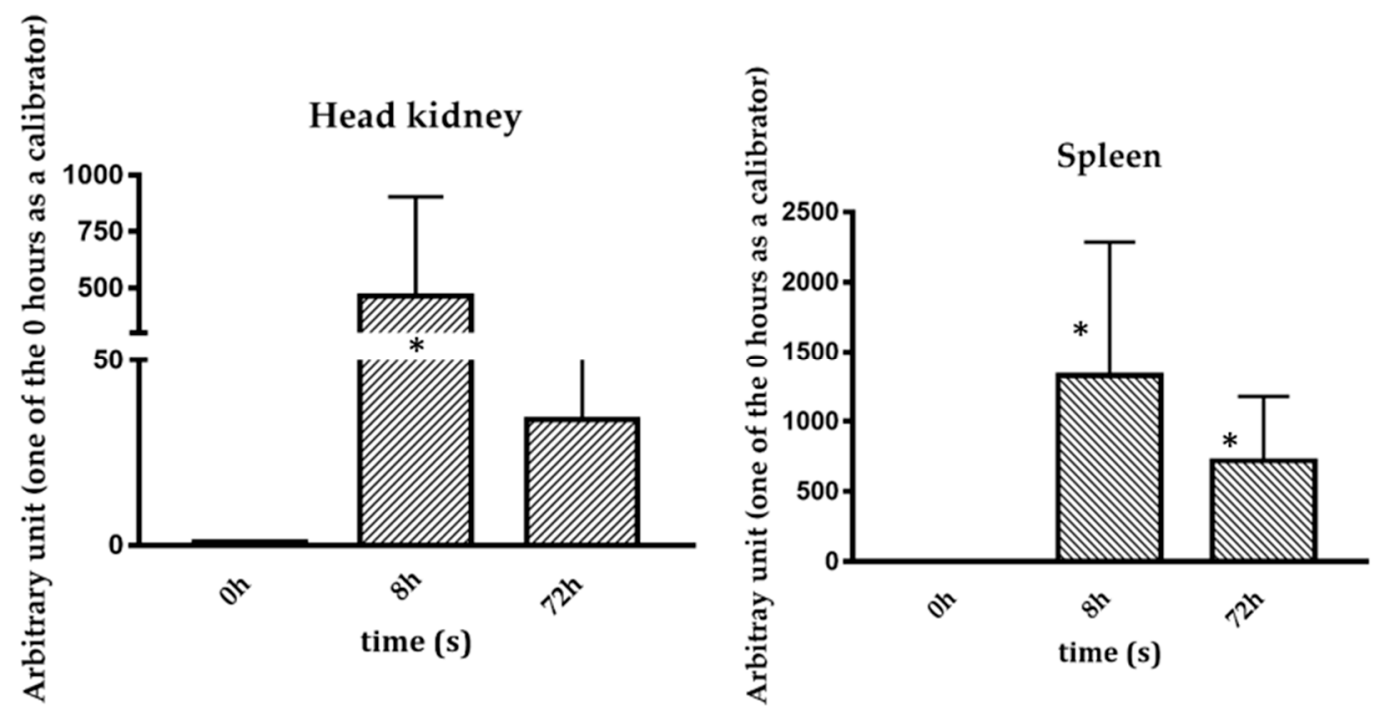

Figure 3. Trematocine expression analysis after in vivo immunization with Psychrobacter sp. TAD1 in head kidney and spleen after $8 \mathrm{~h}$ and $72 \mathrm{~h}$. The results are expressed as mean + SD and the asterisk indicate the significance level with respect to control $(0 \mathrm{~h}) .{ }^{*}=p<0.05$.

(A)

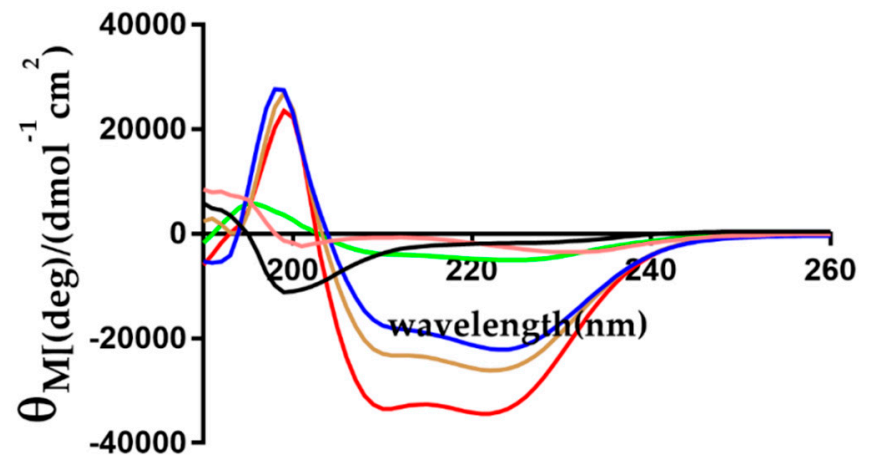

- Trematocine $30 \mu \mathrm{M}$

- P/L 1:2

- P/L 1:4

- P/L 1:8

- P/L 1:13

- P/L 1:30

(B)

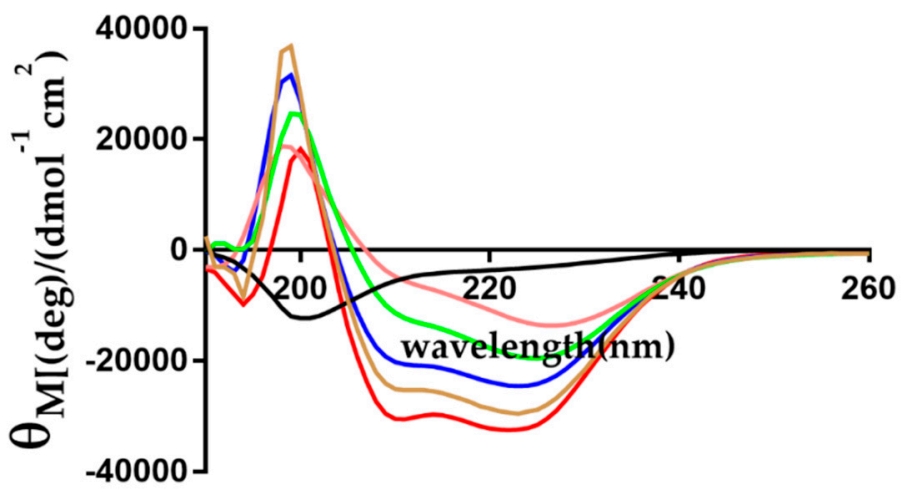

Figure 4. Circular dichroism spectra for Trematocine upon addition (A) 1-palmitoyl-2-oleoyl-snglycero-3-phosphoethanolamine (PE)/1-palmitoyl-2-oleoyl-sn-glycero-3-phosphoglycerol (PG) (3:1) large unilamellar vesicles (LUVs), and (B) 100\% 1-palmitoyl-2-oleoyl-glycero-3-phosphocholine (PC) LUVs. $\mathrm{P} / \mathrm{L}$ ratios are expressed in $\mathrm{mol} / \mathrm{mol}$, and the raw signal is corrected in $\Theta_{\mathrm{M}}$. 


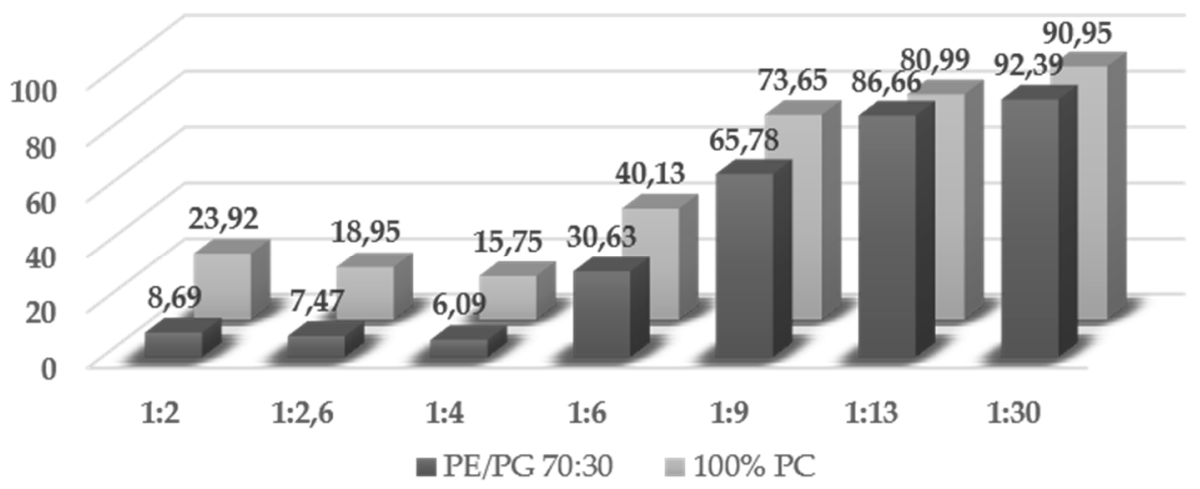

Figure 5. $\alpha$-helix percentages obtained via the K2D3 algorithm using spectra obtained as explained in Section 4.5. A slightly higher helicity in the presence of PE/PG 70:30 LUVs can be noted.

\subsection{Trematocine Model Membranes Interaction}

LUVs are considered a reliable model to study the interaction between a peptide and a double layer. In order to have a suitable curvature radius, we chose to use LUVs with an average diameter of $100 \mathrm{~nm}$. We studied the interaction by steady state fluorescence spectroscopy, following the emission of Trp. To evaluate the interaction between Trematocine and different LUVs, we detected the Trp-1 fluorescence upon partitioning in the presence of LUVs. The Trp emission showed a blue shift and an increase of intensity, typical of a transition from a polar to a non-polar environment. Binding isotherms are reported in Figure 6, and in Table 1 are shown the mole fraction partition constants (1) [27,30].

$$
f_{p}=\frac{K_{x}[L]}{K_{x}[L]+[W]}
$$

These results evidenced that Trematocine interacts with model membranes, with a preference $\left(K_{x}=8.8 \times 10^{4}\right)$ for PC/PG anionic (70:30) LUVs, the most used model for bacterial membranes, while the interaction with PE/PG 3:1 and 100\% 1-palmitoyl-2-oleoyl-glycero-3-phosphocholine (PC) LUVs is weaker $\left(K_{x} \sim 4 \times 10^{4}\right)$. This demonstrates a distinct selectivity towards negatively-charged membranes. Furthermore, to evaluate the topology of the peptide interacting with different LUVs, we studied the quenching of Trp fluorescence by acrylamide. As expected, the Stern-Volmer constants (Table 2) were higher in the buffer $\left(21.2 \mathrm{M}^{-1}\right)$ than in the presence of vesicles $\left(\sim 1 \mathrm{M}^{-1}\right)$. This suggests that the N-terminal Trp of Trematocine is accessible in the buffer while it partitions and inserts in the interfacial region of the double layer in presence of LUVs. We also calculated the Net Accessibility Factor (NAF) [31], defined by Equation (2).

$$
N A F=\frac{K_{S V(L U V)}}{K_{S V(B U F F E R)}}
$$

NAF values, reported in Table 2, were lower in the presence of PE/PG 3:1 LUVs, suggesting a lower accessibility of Trp-1 to the quencher in the presence of phosphatidiletanolammine head groups [32] rather than phosphatidilcoline ones. We then carried out studies of fluorescence anisotropy using the 1,6-Diphenyl-1,3,5-hexatriene (DPH) fluorescent probe. DPH is a compound whose fluorescence anisotropy depends on the membrane fluidity. In Figure 7, the normalized anisotropy of DPH, measured at $25^{\circ} \mathrm{C}$, is reported at different concentrations of peptide. Only for PC/PG LUVs does the anisotropy of DPH vary, indicating a decrease of the membrane fluidity upon addition of peptide (Figure 7). For PC and PE/PG LUVs, the anisotropy is essentially the same, indicating that membrane fluidity is not affected by the addiction of peptide. These studies confirmed the same trend we reported in the partition experiments, showing, a greater interaction between the Trematocine and PC/PG (70:30) double layer rather than 100\% PC and PE/PG (3:1) LUVs. 


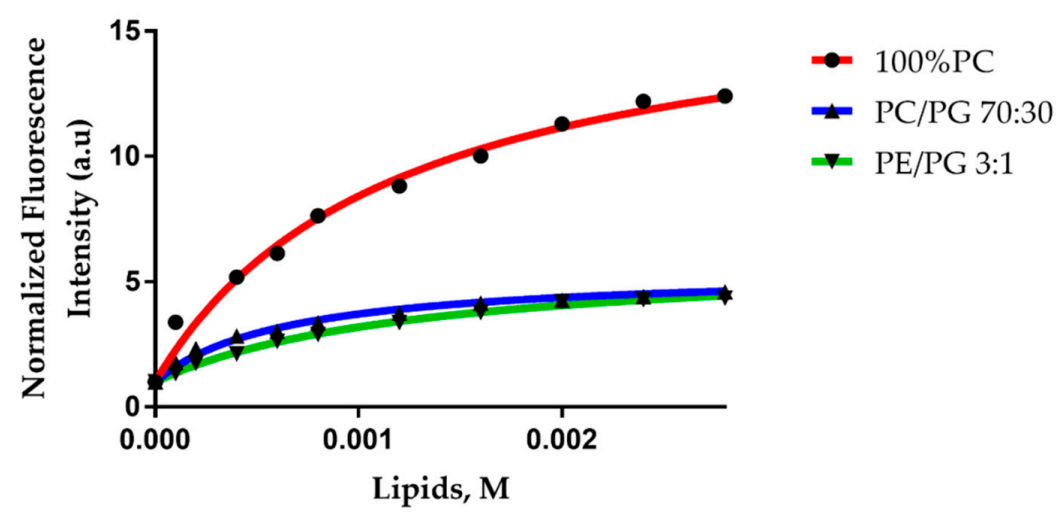

Figure 6. Binding isotherms for Trematocine interacting with LUVs of different compositions. Tryptophan fluorescence was measured. Trematocine concentration was $1 \mu \mathrm{M}$.

Table 1. Partition constant values relative to the different LUV compositions.

\begin{tabular}{ccc}
\hline LUV Composition & $\boldsymbol{K}_{\boldsymbol{x}} \mathbf{( 1 \times \mathbf { 1 0 } ^ { \mathbf { 4 } } )}$ & $\mathbf{r}^{\mathbf{2}}$ \\
\hline PC/PG (70:30) & $8.84 \pm 1.5$ & 0.99 \\
100\% PC & $4.7 \pm 0.6$ & 0.99 \\
PE/PG (3:1) & $4.2 \pm 0.3$ & 0.99 \\
\hline
\end{tabular}

Table 2. Stern-Volmer constant relative to Trematocine in the presence/absence of LUVs of different compositions. Net Accessibility Factor (NAF) is defined as in Equation (2).

\begin{tabular}{ccc}
\hline LUV Composition & $\boldsymbol{K}_{\boldsymbol{S V}}$ & $\mathbf{N A F}_{(\mathbf{1})}$ \\
\hline PC/PG (70:30) & $1.33 \pm 0.05$ & 0.063 \\
100\% PC & $1.31 \pm 0.03$ & 0.062 \\
PE/PG (3:1) & $0.94 \pm 0.06$ & 0.044 \\
Buffer & $21.16 \pm 0.08$ & 1 \\
\hline
\end{tabular}

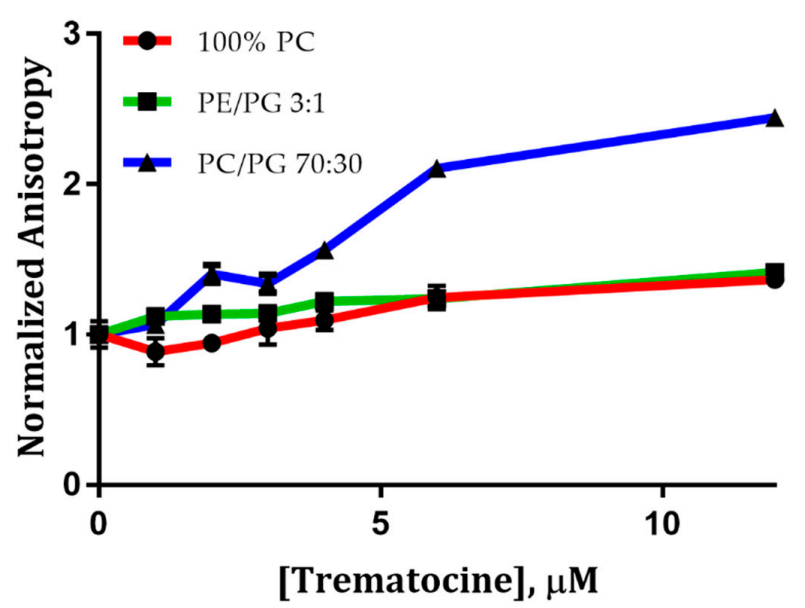

Figure 7. Steady-state fluorescence anisotropy relative to 1,6-Diphenyl-1,3,5-hexatriene (DPH)containing LUVs, upon interaction with Trematocine. Anisotropy was normalized for each experiment with the $\mathrm{r}_{0}$ relative to DPH-containing LUVs in the absence of the peptide.

\subsection{Trematocine Crosses Outer Membrane and Interacts with Inner Membrane}

In order to prove the ability of Trematocine to disrupt the Gram-negative bacteria outer membrane (OM), an ANS assay was performed. As shown in Figure 8, for both E. coli and Psychrobacter sp. TAD1, 
the addition of Trematocine causes a sharp increase of ANS fluorescence, in a dose-dependent way. This is due to the capability of the probe to translocate inside the periplasmatic space because of a perturbation in the lipopolysaccharidic wall. Furthermore, inner membrane (IM) depolarization assay, using a Disc3(5) fluorescent probe, showed that Trematocine can disrupt the electric gradient of $E$. coli, Psychrobacter sp. TAD1, and Bacillus pumilus, a Gram-positive bacteria cell walls in a dose-dependent way (Figure 9), proving again that Trematocine can interfere with the integrity of the anionic-charged phospholipidic double-layer. The effect was more evident on B. pumilus, with a detectable depolarization at a concentration of Trematocine $10 \mathrm{nM}$. Interestingly, for E. coli, an initial hyperpolarization (indicated by the decrease of Disc3(5) fluorescence) has been observed at low peptide concentrations, hinting at the need for a possible threshold concentration to disrupt membrane potential.

(A)

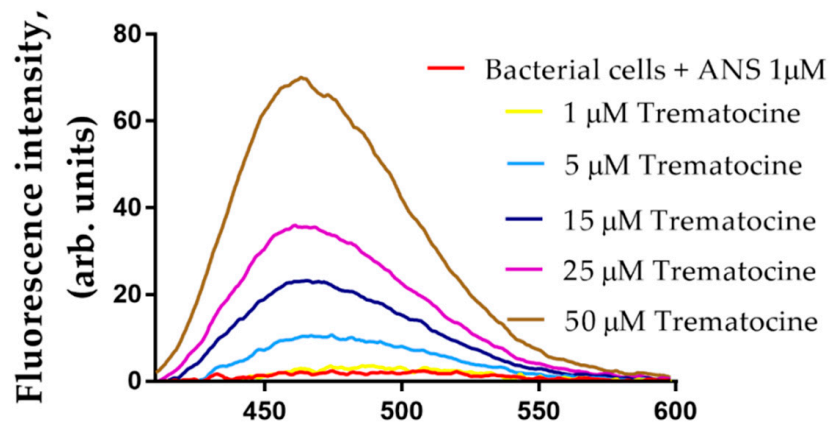

(B)
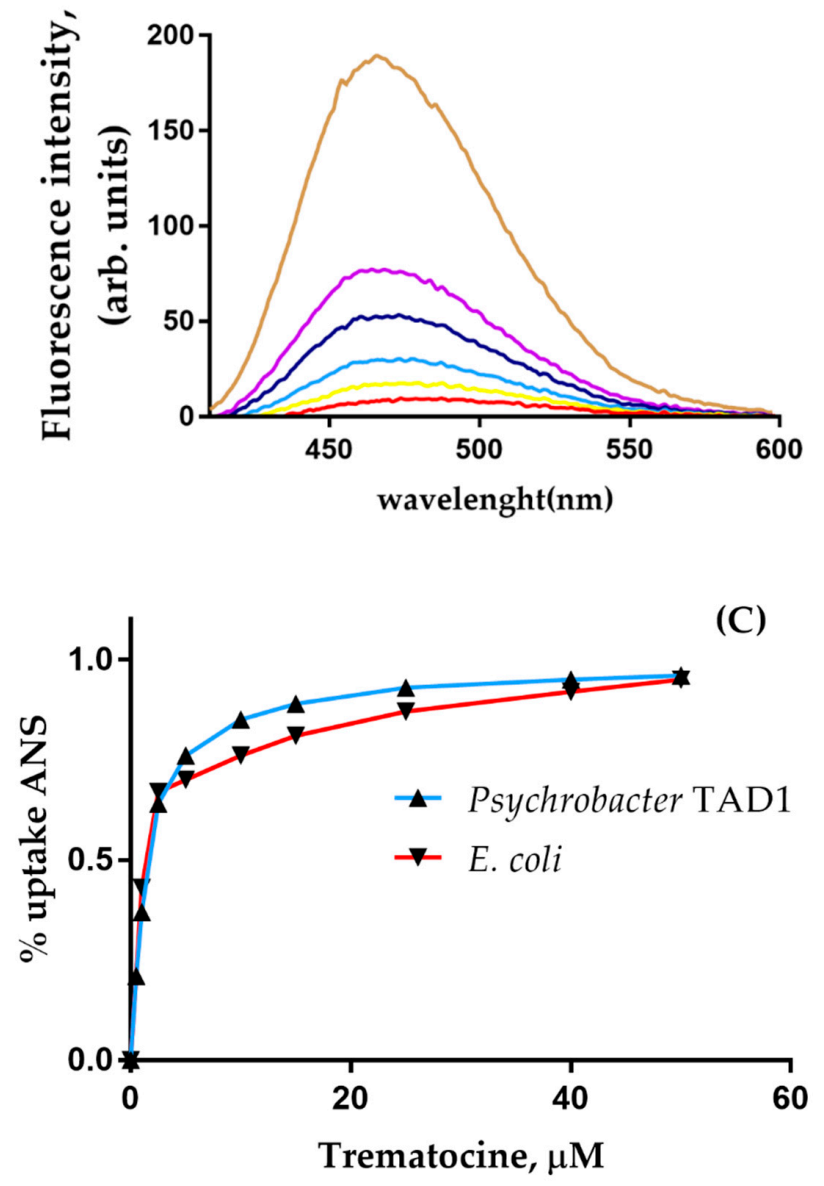

Figure 8. Permeabilization of Psychrobacter TAD1 (A, B) E. coli, outer membrane by Trematocine. (C): percentage of ANS uptake. 

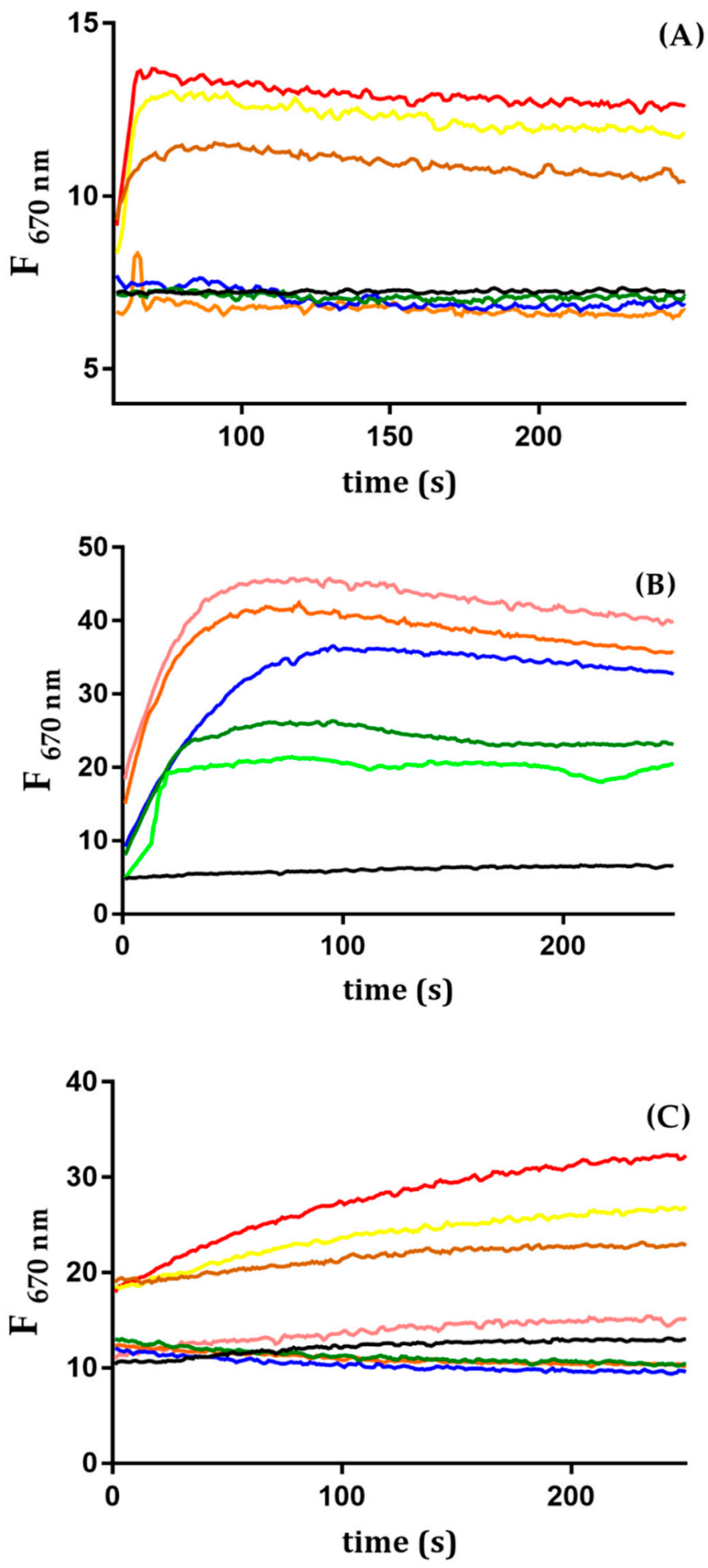

Figure 9. Inner Membrane depolarization measured using Disc3(5): (A) Psychrobacter TAD1, (B) B. pumilus, (C) E. coli at different Trematocine concentrations. For every species, the baseline is in black, then: light green, $10 \mathrm{nM}$; dark green, $20 \mathrm{nM}$; blue, $50 \mathrm{nM}$; orange, $100 \mathrm{nM}$; pink, $250 \mathrm{nM}$; brown, $0.5 \mu \mathrm{M}$; yellow, $1 \mu \mathrm{M}$; and red, $2 \mu \mathrm{M}$.

\subsection{Antimicrobial Activity}

The Trematocine concentrations required to inhibit and kill the tested bacterial strains are summarized in Table 3. Trematocine shows activity against both Gram-positive and Gram-negative 
bacteria. Among all tested bacterial strains, Psychrobacter sp. TAD1 and Bacillus pumilus were the most susceptible. A certain antimicrobial activity was also registered toward yeast cells.

Table 3. Antimicrobial activity of Trematocine.

\begin{tabular}{ccc}
\hline Microrganism & MIC & MBC/MFC \\
\hline & \multicolumn{2}{c}{ Trematocine $(\boldsymbol{\mu M})$} \\
\cline { 2 - 3 } Escherichia coli & 25 & 25 \\
Bacillus pumilus & 10 & 25 \\
Psychrobacter sp. (TAD1) & 2.5 & 10 \\
Candida boidinii & 50 & 100 \\
\hline
\end{tabular}

\subsection{Haemolytic and Cytotoxic Activity}

The hemolytic effect of Trematocine has been tested on rabbit erythrocytes to investigate its capacity to induce membrane lysis. Six different concentrations of peptide have been tested (from $5 \mu \mathrm{M}$ to $200 \mu \mathrm{M})$. Hemolysis rates at the lowest concentrations $(5 \mu \mathrm{M}$ and $10 \mu \mathrm{M})$ are between $1 \%$ and $7 \%$. A notable increase of hemolytic effect can be seen above a concentration of $50 \mu \mathrm{M}$, with a $55 \%$ hemolysis (Figure 10).

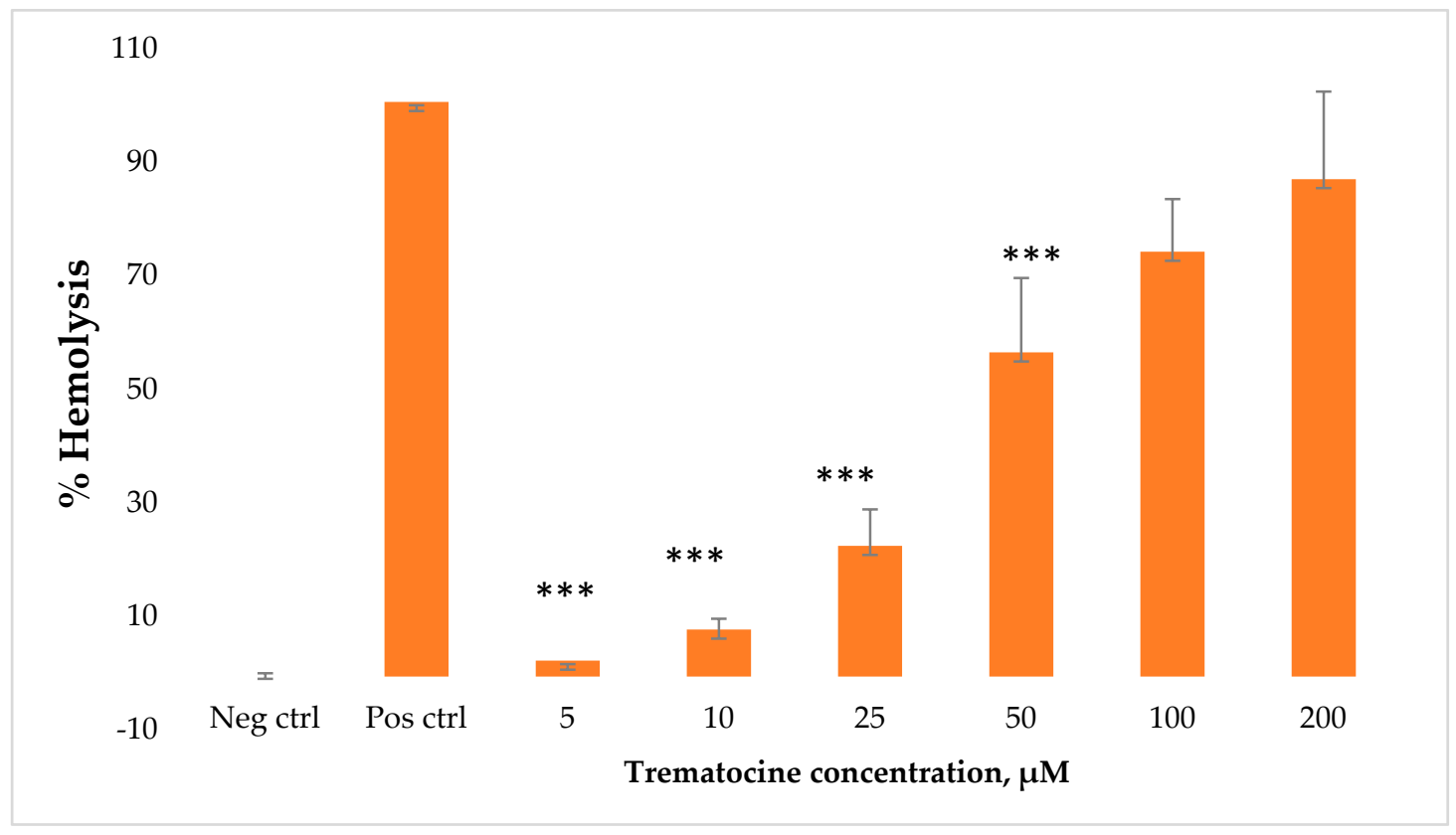

Figure 10. Hemolytic activity of Trematocine against rabbit erythrocytes. Six different concentrations have been tested. The values represent the mean $+\mathrm{SD}$, and the asterisks indicate the significance level with respect to positive control (100\% haemolysis): $p<0.01^{* * *}$.

We have also studied the effect of Trematocine peptide on a primary human fibroblast cell line (FB789). The peptide was tested at six concentrations, and the percentage of cell viability was evaluated after $8 \mathrm{~h}$ and $24 \mathrm{~h}$. The results (Figure 11) showed that Trematocine is toxic at very high concentrations $(100 \mu \mathrm{M}$ and $50 \mu \mathrm{M}$ ), while at lower concentrations (from $25 \mu \mathrm{M}$ to $3.12 \mu \mathrm{M}$ ) it did not show any toxicity. 


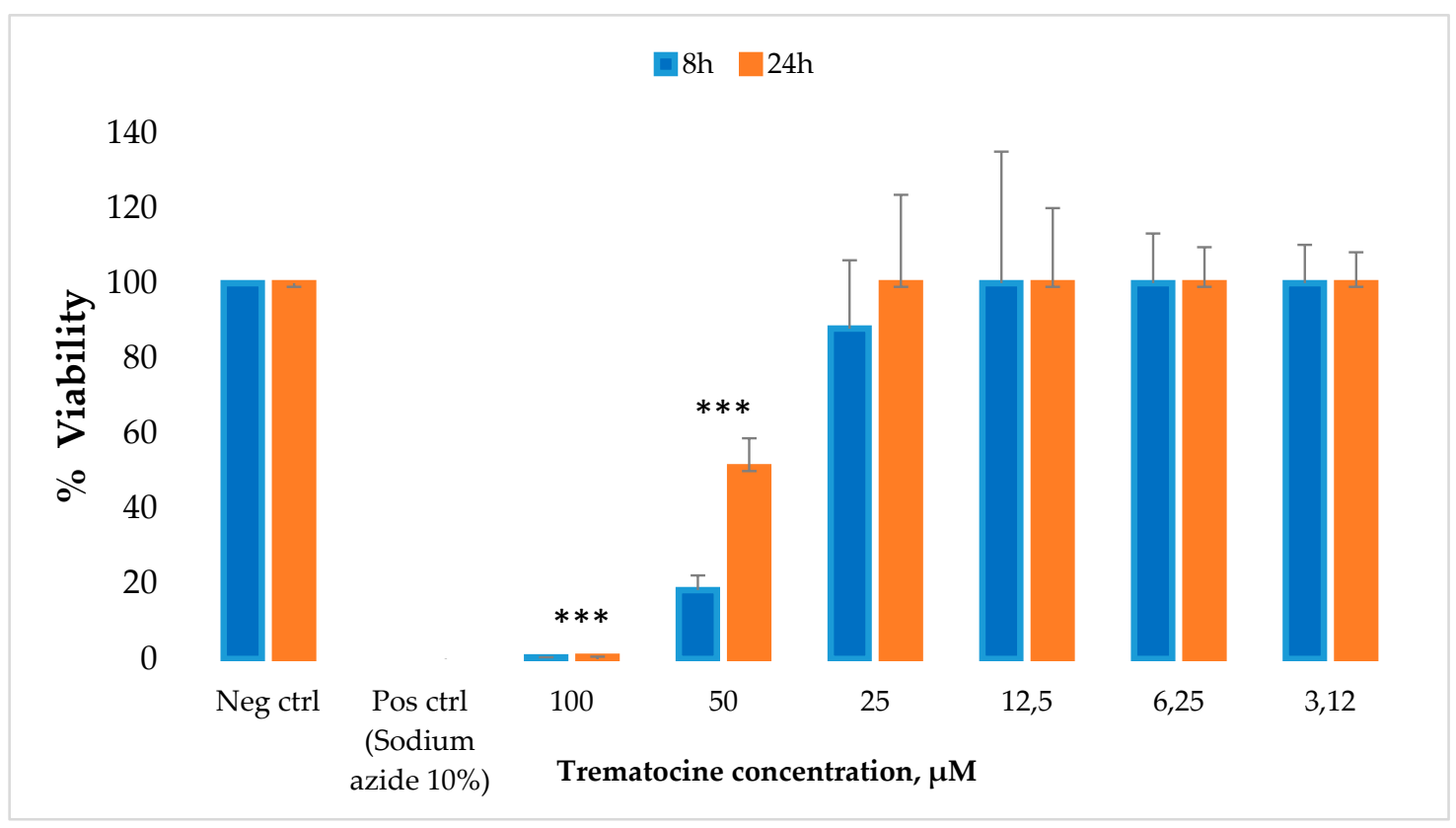

Figure 11. Cytotoxic activity of Trematocine against a primary human fibroblast cell line (FB789). Six different concentrations have been tested. The values represent the mean $+\mathrm{SD}$, and the asterisks indicate the significance level with respect to negative control $\left(100 \%\right.$ of viability). ${ }^{* * *}=p<0.001$.

\section{Discussion}

The current emergence of pathogen antibiotic resistance has given a great boost to the search for novel drugs. Antimicrobial peptides [1] are a widespread and differentiated class of molecules, mainly with antibiotic (and sometimes antifungal and antiviral [33]) properties. Since their discovery in the late 1970s, more than 5000 molecules have been characterized. The sea environment is a rich source of such entities, due to its peculiar microbial promiscuity. In particular, Antarctica has been selected as an excellent field of discovery for new AMPs with specific structures due to its peculiar environmental conditions [25-27]. From the analysis of a Trematomus bernacchii transcriptome [34] we identified a putative sequence of an AMP, included in a family of piscidins that we named Trematocine. It shows a remarkable homology to another AMP we identified from an icefish, the Chionodracine, and lower identity with other AMP from Teleost fish, such as Dicentracine from Dicentarchus labrax [35]. Usually, in mammals, AMPs are produced as pre-pro-peptides and, after secretion, the mature peptide is obtained due to the processing of the pro-peptide by proteases [36]. The only region that is highly conserved in all peptides is the signal peptide and, therefore, it could be argued that they all use the same secretion pathway. To verify that this sequence really corresponds to an AMP involved in the $T$. bernacchii innate immune responses, we investigated its basal expression in different tissues and organs. The highest expression was found in head kidney and the gills; the first is known as the main lymphoid tissue in teleost fishes [33,37,38], whereas the second is the main pathogen portal of entry. High levels of expression in head kidney (HK) have been found for other fish AMPs, like for Dicentracine in sea bass [38] and Epinecidin in orange-spotted grouper [39]. Trematocine expression in T. bernacchii skin —and so, its presence in mucus—is very low compared to other AMP frequently found in fish mucus [40-43]. Thus, probably, Trematocine is mainly a leucocyte effector rather than a first barrier AMP. This could explain its very low cytotoxicity, comparable to other native AMPs with similar expression patterns [26,27]. Furthermore, we attempted to elicit its expression upon stimulation through in vivo immunization with Psychrobacter sp. TAD1, an endemic bacterial pathogen of Antarctica. We showed that the AMP is up-regulated in HK and spleen, as foreseen. In gilt-head seabream, a similar expression pattern was found for a hepcidine [44], and, in Oryza melastigma, upon stimulation with Vibrio parahaemolyticus, a known Gram-negative pathogen bacteria, despite $O$. 
melastigma being evolutionary distant from T. bernacchii. Among piscidins [24,45], GAD-1 and GAD-2 transcripts were up-regulated only in the spleen through the injection of bacterial antigens (ASAL) in Gadus morhua [46]. Given this data, expression in tissue different from gills, spleen, and of course HK, can be explained with the presence of circulating Trematocine-expressing mast cells due to their central role in innate immunity of teleost fishes [47]. Due to these encouraging preliminary results, we decided to investigate the structure of the Trematocine putative mature peptide with the aim of verifying its resemblance to other piscidins. Through circular dichroism spectroscopy, we proved that-as with most helical AMPs-Trematocine is a random coil in the buffer, but it develops a consistent alpha helix structure in the presence of lipid vesicles, both zwitterionicly and anionicly charged. As is peculiar with many AMP families, Trematocine $\alpha$-helix has an amphipatic structure. Trematocine, thus, also exhibits a higher thermodynamic affinity, as it can be inferred by the Wimley [30] partition constants, for anionic charged double layers rather than zwitterionic; this leads to a good selectivity ratio defined by the ratio between the partition constants measured in PC/PG, PE/PG, and POPC [48,49]. Furthermore, as evidenced by Trp quenching analysis, Trematocine deeply inserts into the double layer with a slight preference for 1-palmitoyl-2-oleoyl-sn-glycero-3-phosphoglycerol (PG) containing LUVs, a common feature for cationic charged AMPs [50-54]. Also, fluorescence anisotropy gave some interesting clues about the Trematocine mode of action towards lipid membranes. DPH fluorescence is related to membrane microviscosity [55]; pore-forming drugs and cholesterol usually cause a decrease in membrane anisotropy due to an augmented packing of acyl tails [56-60]. Interestingly, upon addition of Trematocine, DPH fluorescence anisotropy in anionic LUVs increased, thus indicating a different mechanism in the perturbation of the double layer, decreasing its fluidity, in a similar fashion of a bacteriocin, the famous magainin 2 and mellitin [41,61,62], rather than other elicoidal AMPs. All these data, taken together, confirm the hypothesis that Trematocine follows a carpet like mode of action $[14,63]$, as it has been demonstrated for the related Chionodracine $[15,26]$. Further studies (i.e., electronic microscopy and molecular dynamics simulations) are needed to completely elucidate its mechanism of action. However, we decided to explore its antimicrobial activity against bacteria and yeast. Similar Chionodracine behavior has also been observed in term of antimicrobial activity, being Trematocine active toward both Gram-positive and Gram-negative bacteria, with minimum inhibitory concentration (MIC) values around 2.5-25 $\mu \mathrm{M}$, especially against Gram-negative bacteria. Trematocine has also been shown to possess anti-fungal activity against Candida boidinii [64], demonstrating that the peptide, acting on membranes, possessed broad-spectrum antimicrobial activity. To investigate its potential as a new candidate drug we determined both the haemolytic activity against mammalian erythrocytes and the cytotoxicity against a human primary cell line. At the peptide concentration useful to kill the tested bacteria, there is no evidence of any Trematocine negative effect.

\section{Materials and Methods}

\subsection{Identification of an AMP from T. bernacchii}

The nucleotide sequence of a putative antimicrobial peptide was identified from the head kidney transcriptome of T. bernacchii [34]. Adult specimens of Trematomus bernacchii were collected in various Antarctic campaigns by researchers of the Italian National Research Project in Antarctica (PNRA) at the Italian Antarctic Base, Terra Nova Bay, Ross Sea (Mario Zucchelli Station). After collection, fish were placed in tanks with running seawater. Organs and tissues (brain, skin, muscle, head kidney, gills, liver, and gut) from $T$. bernacchii were sampled and homogenized, disrupting them by teasing on a $100 \mathrm{~mm}$ cell strainer; the obtained cells were placed in eppendorfs containing Tripure (Roche, Basel, Switzerland) for total RNA extraction. The total RNA was resuspended in DEPC-treated water. Controls for the quality of cDNA were performed using actin primers that spam an intron (see Table 4). PCR reactions were conducted using a Mastercycler (Eppendorf, Hamburg, Germany). The cycling protocol was one cycle of $94{ }^{\circ} \mathrm{C}$ for $5 \mathrm{~min}, 35$ cycles of $94{ }^{\circ} \mathrm{C}$ for $45 \mathrm{~s}, 52{ }^{\circ} \mathrm{C}$ for $45 \mathrm{~s}$, and $72{ }^{\circ} \mathrm{C}$ for $45 \mathrm{~s}$, followed by one cycle of $72{ }^{\circ} \mathrm{C}$ for $10 \mathrm{~min}$. PCR products were visualized on $1.5 \%(w / v)$ agarose gels 
containing Gel red (Biotium, Fremont, CA, USA) and using hyperladder IV (Bioline, Memphis, TN, USA) as size markers. Further primers (see Table 4) were used to amplify the complete sequence of the Trematocine gene based on the sequence found in the transcriptome using as a template a cDNA from head kidney. The PCR product was purified using a QIAquick Gel Extraction Kit (QIAgen, Hilden, Germany), and it was inserted into the pGEM-T Easy vector (Promega, Madison, WI, USA) and transformed into competent JM 109 Escherichia coli cells. Plasmid DNA was purified using the Wizard Plus SV Minipreps DNA purification System (Promega) and sequenced by Eurofins Genomics (Ebersberg, Germany). The AMP sequence was analyzed for the presence of a signal peptide using SignalP software [65].

Table 4. Primers used for cloning and expression analysis.

\begin{tabular}{ccc}
\hline Gene & Primers Sequence 5 $^{\prime}$-3' $^{\prime}$ (Forward, FW, and Reverse, RV) & Accession Number \\
\hline$\beta$-actin & $\begin{array}{c}\text { ATGTACGTTGCCATCC (FW) } \\
\text { GAGATGCCACGCTCTC (RV) }\end{array}$ & AJ493428 \\
\hline Trematocine & $\begin{array}{c}\text { GTGCACCATCGTCTTTCTGGTGC (FW, complete sequence) } \\
\text { GGCAAACGCTCGCTCTCGGTC (RV, complete sequence) }\end{array}$ & MH325166 \\
\hline Trematocine & $\begin{array}{c}\text { GTGCACCATCGTCTTTCTGGTGC (FW, real-time) } \\
\text { GGCAAACGCTCGCTCTCGGTC (RV, real-time) }\end{array}$ & MH325166 \\
\hline 18 S ribosomal RNA & $\begin{array}{c}\text { CCAACGAGCTGCTGACC (FW, real-time PCR) } \\
\text { CCGTTACCCGTGGTCC (RV, real-time PCR) }\end{array}$ & AY831388 \\
\hline
\end{tabular}

A multiple alignment with other AMP sequences from fish was generated using the CLUSTAL $\omega$ program.

\subsection{Basal Expression of Trematocine}

To investigate the basal expression of Trematocine, three fish were sampled, and some tissues (brain, skin, muscle, head kidney (HK), gills, liver, and gut) were obtained as described above. Total RNA was isolated from each tissue with Tripure (Roche), resuspended in DEPC-treated water, and used for real-time quantitative PCR. The expression level of Chionodracine transcripts was determined with an Mx3000P real-time PCR system (Stratagene, San Diego, CA, USA) equipped with version 4.1 software and using the Brilliant SYBR Green Q-PCR Master Mix (Agilent Technologies, Santa Clara, CA, USA), following the manufacturer's instructions, with ROX as an internal passive reference dye. The reaction was performed using primers for the amplification of about $120 \mathrm{bp}$ of the product from Trematocine and $18 \mathrm{~S}$ ribosomal RNA used as a house-keeping gene (see Table 4). The PCR conditions were: $95^{\circ}$ for $10 \mathrm{~min}$, followed by 35 cycles of $95^{\circ} \mathrm{C}$ for $45 \mathrm{~s}, 52{ }^{\circ} \mathrm{C}$ for $45 \mathrm{~s}$, and $72{ }^{\circ} \mathrm{C}$ for $45 \mathrm{~s}$. Duplicate reactions were performed for each template cDNA. A relative quantitation was performed, comparing the levels of the target transcript (Trematocine) to a reference transcript (calibrator, the tissue with the lowest Trematocine expression), in this case, the brain.

\subsection{Expression after In Vivo Immunization with Psychrobacter sp. TAD1}

The in vivo Trematocine expression was studied using total RNA isolated from head kidney (HK) and spleen from three fish stimulated with Psychrobacter sp. TAD1. $50 \mu \mathrm{L}$ of a solution with Psychrobacter sp. TAD1 adjusted to $10^{9}$ cells $/ \mathrm{mL}$, together with $50 \mu \mathrm{L}$ of Freund's incomplete Adjiuvant, was intraperitoneally injected in fish in Antarctica. After immunization, the fish were placed in aerated tanks until sampling of the selected tissues took place $(8 \mathrm{~h}$ and $72 \mathrm{~h})$. The primers and the real-time PCR conditions were the same as described in the Section 4.2. The calibrator was the time 0 control. The results of all the experiments were expressed as the mean + SD of the results obtained from three fish at each sampled time, and the differences from the control were considered significant if $p<0.05$ using $\mathrm{t}$ two-way ANOVA analysis followed by the Bonferroni's post-test. Duplicate reactions were performed for each template cDNA. 


\subsection{Peptides and LUVs Preparation}

The peptides (98\% purity) were purchased from CASLO ApS (Kongens Lyngby, Denmark). Peptide concentration was determined for each sample preparation by UV light absorption at $280 \mathrm{~nm}$. Large unilamellar vesicles (LUVs) composed, respectively, of 100\% 1-palmitoyl-2oleoyl-sn-glycero-3-phosphocholine (PC), 70\%/30\% (w/w) POPC/1-palmitoyl-2-oleoyl-sn-glycero3-phosphoglycerol (PG), and 3:1 m/m 1-palmitoyl-2-oleoyl-sn-glycero-3-phosphoethanolamine (PE)/PG were prepared according to the general procedures previously reported [15]. Briefly, the lipids, dissolved in chloroform/methanol, 9:1, were dried under rotary evaporation and then overnight under high vacuum. The lipid film was then hydrated in $1 \mathrm{~mL}$ of buffer $(20 \mathrm{mM}$ phosphate buffer at $\mathrm{pH} 7.4$ with $150 \mathrm{mM} \mathrm{NaCl}$ and $0.8 \mathrm{mM}$ EDTA) and subjected to 5 freeze-thaw cycles. The suspension was extruded through a polycarbonate membrane with an Avanti Polar miniextruder (20 times through two-stacked polycarbonate membranes with pore sizes of $100 \mathrm{~nm}$ ), and the obtained LUVs were used within $48 \mathrm{~h}$ of preparation.

\subsection{Circular Dichroism Studies}

The secondary structure of Trematocine (FFGHLLRGIVSVGKHIHGLITG) in the presence of membrane-mimicking systems was evaluated by circular dichroism spectroscopy. All the experiments were carried out on a Jasco spectropolarimeter, with a thermostated cell holder set at $25^{\circ} \mathrm{C}$. The used buffer was $0.01 \mathrm{M} \mathrm{PB}$ and $0.08 \mathrm{mM}$ of EDTA, in order to avoid chlorine anion effects on CD spectra. A $30 \mu \mathrm{M}$ solution of Trematocine was titrated with LUVs of different compositions (100\% PC, 70:30 PC/PG, and 3:1 PE/PG). Successively, the resulting spectra were analyzed with the K2D3 algorithm [29]. The reported CD spectra are the average of 16 scans with a scanning speed of $100 \mathrm{~nm} / \mathrm{min}$, a response time of $4 \mathrm{~s}$, a bandwidth of $1.0 \mathrm{~nm}$, and a step size of $0.1 \mathrm{~nm}$. The obtained data in millidegrees (mdeg) were converted to mean molar ellipticity per residue ( $\left.\mathrm{deg} \mathrm{cm}^{2} \mathrm{dmol}^{-1}\right)$ [66].

\subsection{Steady-State Fluorescence Studies}

All the steady state fluorescence experiments were performed using a Perkin Elmer LS55 operating at $25{ }^{\circ} \mathrm{C}$ in a thermostatic cell holder. The spectra were corrected by subtracting the corresponding blanks. Only in this case did we use a mutant of Trematocine (WFGHLLRGIVSVGKHIHGLITG), in which the first Phe was replaced with a Trp, in order to obtain a stronger signal both in UV/Vis and in the fluorescence analysis.

\subsubsection{Partition Studies}

The ability of peptides to associate with and partition into lipid vesicles was studied by measuring the enhancement of tryptophan fluorescence upon the addition of LUVs. Trp- 1 fluorescence spectra were recorded at wavelengths between 310 and $500 \mathrm{~nm}$, considering an excitation wavelength of $295 \mathrm{~nm}$. Measurements were performed with a cross-oriented configuration of polarizers $\left(\mathrm{Pol}_{\mathrm{em}}=90^{\circ}\right.$ and $P_{o l} l_{e x c}=0^{\circ}$ ) to reduce contributions from vesicles [67]. A $1.0 \mathrm{mM}$ peptide solution in a $10 \mathrm{mM}$ phosphate buffer at pH 7.4 containing $0.8 \mathrm{mM}$ EDTA and $150 \mathrm{mM} \mathrm{NaCl}$ was added to a cuvette and then titrated with LUVs of different compositions (100\% PC, 70:30 PC/PG, and 3:1 PE/PG) with a lipid/peptide ratio ranging from 50 to 500 , as described previously [26,27]. The background effects of both buffer and vesicles were subtracted from each spectrum. Mole fraction partition coefficients, $K x$, were obtained, calculating the fraction of peptide, $f p$, which partitioned into the LUVs $[30,68-70]$. The values of $K x$ were obtained, as described before $[15,27]$.

\subsubsection{Intrinsic Fluorescence Quenching Studies}

Peptide solutions $(5.0 \mathrm{mM})$ in both the absence and presence of LUVs (in a peptide:lipid ratio 1:100), were excited at $295 \mathrm{~nm}$, and fluorescence spectra were recorded from 305 to $500 \mathrm{~nm}$. The samples were titrated by adding increasing amounts of acrilamyde in the range $0.01-0.28 \mathrm{M}$, and spectra 
were recorded with excitation and emission band widths of $5 \mathrm{~nm}$. All the fluorescence spectra were corrected for dilution. Fluorescence intensities were extracted, and the data were fitted according to the Stern-Volmer equation, as described previously [26,27,45].

\subsubsection{Outer Membrane Permeability Essay}

The permeabilization assay was carried out using the fluorescent probe 1-aminonaphtalene8-sulfonic acid (ANS), as previously described [26,27,71]. E. coli, Psychrobacter sp. TAD1 [26], and Bacillus pumilus strains were grown at 37,15 , and $28^{\circ} \mathrm{C}$, respectively, to mid-log phase in Luria Bertani (LB) broth (Sigma, Darmstadt, Germany); when the corrected growth phase was reached, they were centrifuged at $3000 \times g$, washed, and suspended in $10 \mathrm{mM}$ Tris- $\mathrm{HCl}, 150 \mathrm{mM} \mathrm{NaCl}$, and $0.8 \mathrm{mM}$ EDTA (pH 7.4) buffer, to give an $\mathrm{OD}_{600}$ of 0.6. Subsequently, increasing amounts of the Trematocine (from 1.0 to $50 \mu \mathrm{M}$ ) were added to a quartz cuvette containing $1.0 \mathrm{~mL}$ of cell suspension and $5.0 \mu \mathrm{M}$ ANS. Fluorescence spectra were recorded at wavelengths between 400 and $600 \mathrm{~nm}$ with an excitation wavelength of $360 \mathrm{~nm}$. The excitation and emission slit widths were $5 \mathrm{~nm}$. After the peptide effect, the ANS was incorporated into the periplasm and, consequently, the fluorescence intensity increased and blue shifted.

\subsubsection{Inner Membrane Depolarization Essay}

In order to determine if there is any depolarization effect on the above-inidicated bacterial strains, Disc3(5) cyanine dye was used [72]. A cell suspension of each selected bacteria (E. coli, B. pumilus, Psychrobacter TAD1) was incubated with $3 \mu \mathrm{M}$ Disc3(5) at the right growth temperature, under agitation, for at least half an hour, to allow the probe to insert inside the inner membrane; it was noticed that, according to cell diameter, the optimal $\mathrm{OD}_{600}$ was different for each cell type. All the experiments were carried out in the dark in order to avoid photobleaching of the Disc3(5) probe. When a stable decrease in fluorescence was reached, different $1 \mathrm{~mL}$ samples were prepared, with Trematocine concentrations ranging from $20 \mathrm{nM}$ to $2 \mu \mathrm{M}$. Disc3(5) was excited at $622 \mathrm{~nm}$, and its $670 \mathrm{~nm}$ fluorescence emission was recorded in a time-driven experiment. For E. coli, the assay was optimized for an $\mathrm{OD}_{600}$ of 0.17 , for Bacillus pumilus of 0.02, and for Psychrobacter TAD1 of 0.11 .

\subsubsection{Fluorescence Anisotropy Studies}

Diphenil exatrien probe (DPH), a lipid-like molecule, was added to the lipidic mixture dissolved in chloroform/methanol 9:1 in a 1:1000 ratio with respect to lipid from an ethanol stock; the LUVs were then prepared as described above. It has been proven that DPH has a negligible effect on bilayer fluidity at this lipid/probe ratio [73]. DPH fluorescence anisotropy was then recorded upon the addition of 1 to $12 \mu \mathrm{M}$ Trematocine to a $200 \mu \mathrm{M}$ lipid suspensions of LUVs of different compositions $(100 \%$ $\mathrm{PC}, 70: 30 \mathrm{PC} / \mathrm{PG}$, and 3:1 PE/PG), with $5 \mathrm{~nm}$ emission and excitation bandwidths and $360 \mathrm{~nm} / 450 \mathrm{~nm}$ excitation/emission wavelengths, respectively. Anisotropy $(r)$ values were normalized using $r_{0}$ LUVs values, i.e., in the absence of Trematocine.

\subsection{Antimicrobial Activity of Trematocine}

The antimicrobial activity of Trematocine peptide was examined against the yeast Candida boidinii, the Gram-positive bacteria Bacillus pumilus, and two Gram-negative bacteria, Escherichia coli and Psychrobacter sp. TAD1. MIC was determined by the broth microdilution method in 96 well polystyrene microplates Greiner Bio-One ${ }^{\mathrm{TM}}$ (Sigma Darmstadt, Germany) and streptomycin sulfate was used as the positive control. Besides Psychrobacter sp. TAD1, which was grown at $15{ }^{\circ} \mathrm{C}$, all the other strains were grown aerobically and cultured at $28^{\circ} \mathrm{C}$. The growth medium without peptide was used as the negative control. The peptide was diluted $(0.5-100 \mu \mathrm{M})$ in Mueller Hinton Broth, and $100 \mu \mathrm{L}$ of each dilution was dispensed into each well. The inoculum suspension was adjusted to achieve $5 \times 10^{6} \mathrm{CFU} \mathrm{mL} \mathrm{mL}^{-1}$. The MIC was defined as the lowest concentration of the peptide that totally inhibited the growth. An aliquot $(5 \mu \mathrm{L})$ of the cell suspension was taken from the above MIC microwell plate, and the cell suspension was plated on an LB agar Potato Dextrose Agar (PDA), for determining Minimal bactericidal 
Concentration (MBC) and Minimum Fungicidal Concentration (MFC), respectively. The MBC and MBT were defined as the lowest peptide concentrations at which more than $99.9 \%$ of the cells were killed compared with an untreated control.

\subsection{Haemolytic Activity Assay}

The haemolytic assay was performed against rabbit erythrocytes maintained in Alsever's solution (Innovative Research). Before the assay, the Alsever's solution was removed and erythrocytes were resuspended in PBS 1X. Erythrocytes were successively counted, and a suspension of 5,000,000 red blood cells was incubated with serial dilutions (from $5 \mu \mathrm{M}$ to $200 \mu \mathrm{M}$, six dilutions) of Trematocine. As a negative control, we used erythrocytes in PBS, while as a positive control we used erythrocytes in triton $10 \% \mathrm{v} / \mathrm{v}$. The plate was incubated at $37^{\circ} \mathrm{C}$ for $2 \mathrm{~h}$ and subsequently centrifuged at $1200 \mathrm{rpm} \times 3 \mathrm{~min}$ to separate the pellet from the supernatant. Each point was made in triplicate. The absorbance was measured at $570 \mathrm{~nm}$. The relative OD compared to the positive control defined the percentage of haemolysis [74].

\subsection{Cytotoxicity Assay}

The cytotoxicity of the peptide was tested on primary human fibroblast cell lines (FB789) grown in Dulbecco's Modified Eagle Medium (DMEM). The cytotoxicity of Trematocine was determined by measuring the intracellular adenosine triphosphate (ATP) levels using the luciferase-based ATPlite assay (PerkinElmer, Waltham, MA, USA), according to the maufacturer's instructions. Cells were seeded on 96-well microplates at a concentration of $5 \times 10^{3}$ cells per well in $100 \mu \mathrm{L}$ of medium for $8 \mathrm{~h}$ and $24 \mathrm{~h}$ at $37^{\circ} \mathrm{C}$ in a humidified incubator with $5 \% \mathrm{CO}_{2}$ atmosphere. Serial dilutions of peptide solutions (from $3.12 \mu \mathrm{M}$ to $100 \mu \mathrm{M}$, six dilutions) dissolved in water were added; as a negative control the ATP level in cells grown in normal medium without the peptide was used, while as a positive control, cells added with NaN3 10\% v/v were used. After 8 and 24 h, the cells were lysed, and the lysates were transferred into opaque well plates (Optiplate-96, PerkinElmer). Emitted light amount, linearly correlated with ATP concentration, was measured with a microplate luminometer (Victor II PerkinElmer) for $10 \mathrm{~min}$ in the dark. Three replicates for each dilution were performed. Cell viability values were expressed as the mean + SD and calculated as the percent values of the treated samples with respect to the untreated cells. The differences from the control were considered significant if $p<0.05$, using two-way ANOVA analysis followed by the Bonferroni's post-test.

\section{Conclusions}

In conclusion, we have identified a new antimicrobial peptide from a very peculiar source; a fish from Antarctica. We evidenced that it interacts with and creates pores on bacteria cell membranes and we determined its high antimicrobial activity against some model Gram-negative bacteria. Moreover, we demonstrated that it exerts no toxicity against both erythrocytes and primary mammalian cell lines. This new antibiotic molecule will be successively tested against drug-resistant human pathogens to verify the possible use as an alternative antimicrobial agent in conjunction with studies related to the analysis of its pharmacokinetics and pharmacodynamics properties.

Author Contributions: G.D.P., G.P., M.C.B., and M.F., methodology and investigation; M.G., software; G.D.P., G.P., S.C., and F.B., writing-original draft preparation; F.P., S.C., and F.B., writing-review and editing; F.C. and G.S., supervision. All authors have read and agreed to the published version of the manuscript.

Funding: This research was partially funded by the PRONAT project supported by CNCCS s.c.s.r.l., by the "Department of Excellence-2018" Program (Dipartimenti di Eccellenza) of the Italian Ministry of Education, University and Research, DIBAF-Department of University of Tuscia, and by the Italian Program of Antarctic Research (Project PNRA18_00077).

Conflicts of Interest: The authors declare no conflict of interest. The funders had no role in the design of the study; in the collection, analyses, or interpretation of data; in the writing of the manuscript, or in the decision to publish the results. 


\section{Abbreviations}

$\begin{array}{ll}\text { AMP } & \text { antimicrobial peptide } \\ \text { DPH } & \text { 1,6-diphenil-exatrien } \\ \text { OM } & \text { outer membrane } \\ \text { IM } & \text { inner membrane } \\ \text { PC } & \text { 1-palmitoyl-2-oleoyl-glycero-3-phosphocholine } \\ \text { PG } & \text { 1-palmitoyl-2-oleoyl-sn-glycero-3-phosphoglycerol } \\ \text { PE } & \text { 1-palmitoyl-2-oleoyl-sn-glycero-3-phosphoethanolamine } \\ \text { MIC } & \text { minimum inhibitory concentration } \\ \text { MBC } & \text { minimum bactericidal concentration } \\ \text { MFC } & \text { minimum fungicidal concentration } \\ \text { CFU } & \text { colony forming units } \\ \text { LUV } & \text { large unilamellar vesicle } \\ \text { DEPC } & \text { diethyl pyrocarbonate } \\ \text { ROX } & \text { 6-carboxy-X-rhodamine } \\ \text { EDTA } & \text { ethylenediamin tetraacetic acid } \\ \text { PBS } & \text { phosphate buffered saline } \\ \text { OD } & \text { optical density } \\ \text { ANS } & \text { 1-aminonaphtalene-8-sulfonic acid }\end{array}$

\section{References}

1. Zasloff, M. Antimicrobial peptides of multicellular organisms. Nature 2002, 415, 389-395. [CrossRef]

2. Bulet, P.; Stöcklin, R.; Menin, L. Anti-microbial peptides: From invertebrates to vertebrates. Immunol. Rev. 2004, 198, 169-184. [CrossRef]

3. Bulet, P.; Hetru, C.; Dimarcq, J.L.; Hoffmann, D. Antimicrobial peptides in insects; structure and function. Dev. Comp. Immunol. 1999, 23, 329-344. [CrossRef]

4. Leippe, M. Antimicrobial and cytolytic polypeptides of amoeboid protozoa-Effector molecules of primitive phagocytes. Dev. Comp. Immunol. 1999, 23, 267-279. [CrossRef]

5. García-Olmedo, F.; Molina, A.; Alamillo, J.M.; Rodriguez-Palenzuéla, P. Plant defense peptides. Biopolymers 1998, 47, 479-491. [CrossRef]

6. Stotz, H.U.; Waller, F.; Wang, K. Innate immunity in plants: The role of antimicrobial peptides. In Antimicrobial Peptides and Innate Immunity; Springer: Basel, Switzerland, 2013; pp. 29-51. ISBN 9783034805414.

7. Ng, T.; Cheung, R.; Wong, J.; Ye, X. Antimicrobial Activity of Defensins and Defensin-Like Peptides with Special Emphasis on those from Fungi and Invertebrate Animals. Curr. Protein Pept. Sci. 2013, 14, 515-531. [CrossRef]

8. Mygind, P.H.; Fischer, R.L.; Schnorr, K.M.; Hansen, M.T.; Sönksen, C.P.; Ludvigsen, S.; Raventós, D.; Buskov, S.; Christensen, B.; De Maria, L.; et al. Plectasin is a peptide antibiotic with therapeutic potential from a saprophytic fungus. Nature 2005, 437, 975-980. [CrossRef]

9. Hoffmann, J.A.; Kafatos, F.C.; Janeway, C.A.; Ezekowitz, R.A.B. Phylogenetic perspectives in innate immunity. Science 1999, 284, 1313-1318. [CrossRef]

10. Mukherjee, S.; Hooper, L.V. Antimicrobial defense of the intestine. Immunity 2015, 42, 28-39. [CrossRef]

11. Pasupuleti, M.; Schmidtchen, A.; Malmsten, M. Antimicrobial peptides: Key components of the innate immune system. Crit. Rev. Biotechnol. 2012, 32, 143-171. [CrossRef]

12. Reddy, K.V.R.; Yedery, R.D.; Aranha, C. Antimicrobial peptides: Premises and promises. Int. J. Antimicrob. Agents 2004, 24, 536-547. [CrossRef] [PubMed]

13. Campagna, S.; Saint, N.; Molle, G.; Aumelas, A. Structure and mechanism of action of the antimicrobial peptide piscidin. Biochemistry 2007, 46, 1771-1778. [CrossRef] [PubMed]

14. Shai, Y. Mechanism of the binding, insertion and destabilization of phospholipid bilayer membranes by $\alpha$-helical antimicrobial and cell non-selective membrane-lytic peptides. Biochim. Biophys. Acta Biomembr. 1999, 1462, 55-70. [CrossRef] 
15. Buonocore, F.; Picchietti, S.; Porcelli, F.; Della Pelle, G.; Olivieri, C.; Poerio, E.; Bugli, F.; Menchinelli, G.; Sanguinetti, M.; Bresciani, A.; et al. Fish-derived antimicrobial peptides: Activity of a chionodracine mutant against bacterial models and human bacterial pathogens. Dev. Comp. Immunol. 2019, 96. [CrossRef]

16. Porcelli, F.; Verardi, R.; Shi, L.; Henzler-Wildman, K.A.; Ramamoorthy, A.; Veglia, G. NMR structure of the cathelicidin-derived human antimicrobial peptide LL-37 in dodecylphosphocholine micelles. Biochemistry 2008, 47, 5565-5572. [CrossRef]

17. Talandashti, R.; Mahdiuni, H.; Jafari, M.; Mehrnejad, F. Molecular Basis for Membrane Selectivity of Antimicrobial Peptide Pleurocidin in the Presence of Different Eukaryotic and Prokaryotic Model Membranes. J. Chem. Inf. Model. 2019, 59, 3262-3276. [CrossRef]

18. Lad, M.D.; Birembaut, F.; Clifton, L.A.; Frazier, R.A.; Webster, J.R.P.; Green, R.J. Antimicrobial peptide-lipid binding interactions and binding selectivity. Biophys. J. 2007, 92, 3575-3586. [CrossRef]

19. Almeida, P.F.; Pokorny, A. Mechanisms of antimicrobial, cytolytic, and cell-penetrating peptides: From kinetics to thermodynamics. Biochemistry 2009, 48, 8083-8093. [CrossRef]

20. Costa, F.; Teixeira, C.; Gomes, P.; Martins, M.C.L. Clinical application of AMPs. In Advances in Experimental Medicine and Biology; Springer: New York, NY, USA, 2019; Volume 1117, pp. 281-298.

21. Mader, J.S.; Hoskin, D.W. Cationic antimicrobial peptides as novel cytotoxic agents for cancer treatment. Expert Opin. Investig. Drugs 2006, 15, 933-946. [CrossRef]

22. Zheng, Z.; Tharmalingam, N.; Liu, Q.; Jayamani, E.; Kim, W.; Fuchs, B.B.; Zhang, R.; Vilcinskas, A.; Mylonakis, E. Synergistic efficacy of Aedes aegypti antimicrobial peptide cecropin A2 and tetracycline against Pseudomonas aeruginosa. Antimicrob. Agents Chemother. 2017, 61. [CrossRef]

23. Seo, M.D.; Won, H.S.; Kim, J.H.; Mishig-Ochir, T.; Lee, B.J. Antimicrobial peptides for therapeutic applications: A review. Molecules 2012, 17, 12276-12286. [CrossRef] [PubMed]

24. Noga, E.J.; Silphaduang, U. Piscidins: A novel family of peptide antibiotics from fish. Drug News Perspect. 2003, 16, 87-92. [CrossRef] [PubMed]

25. Shin, S.C.; Ahn, I.H.; Ahn, D.H.; Lee, Y.M.; Lee, J.; Lee, J.H.; Kim, H.-W.; Park, H. Characterization of Two Antimicrobial Peptides from Antarctic Fishes (Notothenia coriiceps and Parachaenichthys charcoti). PLoS ONE 2017, 12, e0170821. [CrossRef] [PubMed]

26. Olivieri, C.; Buonocore, F.; Picchietti, S.; Taddei, A.R.; Bernini, C.; Scapigliati, G.; Dicke, A.A.; Vostrikov, V.V.; Veglia, G.; Porcelli, F. Structure and membrane interactions of chionodracine, a piscidin-like antimicrobial peptide from the icefish Chionodraco hamatus. Biochim. Biophys. Acta Biomembr. 2015, 1848, 1285-1293. [CrossRef]

27. Olivieri, C.; Bugli, F.; Menchinelli, G.; Veglia, G.; Buonocore, F.; Scapigliati, G.; Stocchi, V.; Ceccacci, F.; Papi, M.; Sanguinetti, M.; et al. Design and characterization of chionodracine-derived antimicrobial peptides with enhanced activity against drug-resistant human pathogens. RSC Adv. 2018, 8, 41331-41346. [CrossRef]

28. Rodger, A. Near UV Protein CD. In Encyclopedia of Biophysics; Springer: Berlin/Heidelberg, Germany, 2013; p. 1694.

29. Louis-Jeune, C.; Andrade-Navarro, M.A.; Perez-Iratxeta, C. Prediction of protein secondary structure from circular dichroism using theoretically derived spectra. Proteins Struct. Funct. Bioinforma. 2012, 80, 374-381. [CrossRef]

30. Wimley, W.C.; White, S.H. Membrane Partitioning: Distinguishing Bilayer Effects from the Hydrophobic Effect. Biochemistry 1993, 32, 6307-6312. [CrossRef]

31. Saikia, K.; Chaudhary, N. Interaction of MreB-derived antimicrobial peptides with membranes. Biochem. Biophys. Res. Commun. 2018, 498, 58-63. [CrossRef]

32. Murzyn, K.; Róg, T.; Pasenkiewicz-Gierula, M. Phosphatidylethanolamine-phosphatidylglycerol bilayer as a model of the inner bacterial membrane. Biophys. J. 2005, 88, 1091-1103. [CrossRef]

33. Hancock, R.E.W.; Diamond, G. The role of cationic antimicrobial peptides in innate host defences. Trends Microbiol. 2000, 8, 402-410. [CrossRef]

34. Gerdol, M.; Buonocore, F.; Scapigliati, G.; Pallavicini, A. Analysis and characterization of the head kidney transcriptome from the Antarctic fish Trematomus bernacchii (Teleostea, Notothenioidea): A source for immune relevant genes. Mar. Genomics 2015, 20, 13-15. [CrossRef] [PubMed] 
35. Salerno, G.; Parrinello, N.; Roch, P.; Cammarata, M. cDNA sequence and tissue expression of an antimicrobial peptide, dicentracin; a new component of the moronecidin family isolated from head kidney leukocytes of sea bass, Dicentrarchus labrax. Comp. Biochem. Physiol. B Biochem. Mol. Biol. 2007, 146, 521-529. [CrossRef] [PubMed]

36. Wiesner, J.; Vilcinskas, A. Antimicrobial peptides: The ancient arm of the human immune system. Virulence 2010, 1, 440-464. [CrossRef]

37. Geven, E.J.W.; Klaren, P.H.M. The teleost head kidney: Integrating thyroid and immune signalling. Dev. Comp. Immunol. 2017, 66, 73-83. [CrossRef] [PubMed]

38. Uribe, C.; Folch, H.; Enriquez, R.; Moran, G. Innate and adaptive immunity in teleost fish: A review. Vet. Med. (Praha) 2011, 56, 486-503. [CrossRef]

39. Pan, C.Y.; Chen, J.Y.; Cheng, Y.S.E.; Chen, C.Y.; Ni, I.H.; Sheen, J.F.; Pan, Y.L.; Kuo, C.M. Gene expression and localization of the epinecidin-1 antimicrobial peptide in the grouper (Epinephelus coioides), and its role in protecting fish against pathogenic infection. DNA Cell Biol. 2007, 26, 403-413. [CrossRef]

40. Ebran, N.; Julien, S.; Orange, N.; Saglio, P.; Lemaître, C.; Molle, G. Pore-forming properties and antibacterial activity of proteins extracted from epidermal mucus of fish. Comp. Biochem. Physiol. A Mol. Integr. Physiol. 1999, 122, 181-189. [CrossRef]

41. Subramanian, S.; Ross, N.W.; MacKinnon, S.L. Comparison of antimicrobial activity in the epidermal mucus extracts of fish. Comp. Biochem. Physiol. B Biochem. Mol. Biol. 2008, 150, 85-92. [CrossRef]

42. Austin, B.; Mcintosh, D. Natural antibacterial compounds on the surface of rainbow trout, Salmo gairdneri Richardson. J. Fish Dis. 1988, 11, 275-277. [CrossRef]

43. Rakers, S.; Niklasson, L.; Steinhagen, D.; Kruse, C.; Schauber, J.; Sundell, K.; Paus, R. Antimicrobial peptides (AMPs) from fish epidermis: Perspectives for investigative dermatology. J. Invest. Dermatol. 2013, 133, 1140-1149. [CrossRef]

44. Cuesta, A.; Meseguer, J.; Esteban, M.Á. The antimicrobial peptide hepcidin exerts an important role in the innate immunity against bacteria in the bony fish gilthead seabream. Mol. Immunol. 2008, 45, 2333-2342. [CrossRef] [PubMed]

45. Park, N.G.; Silphaduang, U.; Moon, H.S.; Seo, J.K.; Corrales, J.; Noga, E.J. Structure-Activity Relationships of Piscidin 4, a Piscine Antimicrobial Peptide. Biochemistry 2011, 50, 3288-3299. [CrossRef] [PubMed]

46. Browne, M.J.; Feng, C.Y.; Booth, V.; Rise, M.L. Characterization and expression studies of Gaduscidin-1 and Gaduscidin-2; paralogous antimicrobial peptide-like transcripts from Atlantic cod (Gadus morhua). Dev. Comp. Immunol. 2011, 35, 399-408. [CrossRef] [PubMed]

47. Reite, O.B. Mast cells/eosinophilic granule cells of teleostean fish: A review focusing on staining properties and functional responses. Fish Shellfish Immunol. 1998, 8, 489-513. [CrossRef]

48. Dathe, M.; Wieprecht, T. Structural features of helical antimicrobial peptides: Their potential to modulate activity on model membranes and biological cells. Biochim. Biophys. Acta Biomembr. 1999, 1462, 71-87. [CrossRef]

49. Chen, Y.; Mant, C.T.; Farmer, S.W.; Hancock, R.E.W.; Vasil, M.L.; Hodges, R.S. Rational design of $\alpha$-helical antimicrobial peptides with enhanced activities and specificity/therapeutic index. J. Biol. Chem. 2005, 280, 12316-12329. [CrossRef]

50. Mason, A.J.; Marquette, A.; Bechinger, B. Zwitterionic phospholipids and sterols modulate antimicrobial peptide-induced membrane destabilization. Biophys. J. 2007, 93, 4289-4299. [CrossRef]

51. El Jastimi, R.; Edwards, K.; Lafleur, M. Characterization of permeability and morphological perturbations induced by nisin on phosphatidylcholine membranes. Biophys. J. 1999, 77, 842-852. [CrossRef]

52. Kumagai, P.S.; Sousa, V.K.; Donato, M.; Itri, R.; Beltramini, L.M.; Araujo, A.P.U.; Buerck, J.; Wallace, B.A.; Lopes, J.L.S. Unveiling the binding and orientation of the antimicrobial peptide Plantaricin 149 in zwitterionic and negatively charged membranes. Eur. Biophys. J. 2019, 48, 621-633. [CrossRef]

53. Fensterseifer, I.C.M.; Felício, M.R.; Alves, E.S.F.; Cardoso, M.H.; Torres, M.D.T.; Matos, C.O.; Silva, O.N.; Lu, T.K.; Freire, M.V.; Neves, N.C.; et al. Selective antibacterial activity of the cationic peptide PaDBS1R6 against Gram-negative bacteria. Biochim. Biophys. Acta Biomembr. 2019, 1861, 1375-1387. [CrossRef]

54. Santos, D.M.; Verly, R.M.; Piló-Veloso, D.; De Maria, M.; De Carvalho, M.A.R.; Cisalpino, P.S.; Soares, B.M.; Diniz, C.G.; Farias, L.M.; Moreira, D.F.F.; et al. LyeTx I, a potent antimicrobial peptide from the venom of the spider Lycosa erythrognatha. Amino Acids 2010, 39, 135-144. [CrossRef] [PubMed] 
55. Poojari, C.; Wilkosz, N.; Lira, R.B.; Dimova, R.; Jurkiewicz, P.; Petka, R.; Kepczynski, M.; Róg, T. Behavior of the DPH fluorescence probe in membranes perturbed by drugs. Chem. Phys. Lipids 2019, 223. [CrossRef] [PubMed]

56. Park, Y.; Lee, D.G.; Jang, S.H.; Woo, E.R.; Jeong, H.G.; Choi, C.H.; Hahm, K.S. A Leu-Lys-rich antimicrobial peptide: Activity and mechanism. Biochim. Biophys. Acta Proteins Proteomics 2003, 1645, 172-182. [CrossRef]

57. Stott, B.M.; Vu, M.P.; McLemore, C.O.; Lund, M.S.; Gibbons, E.; Brueseke, T.J.; Wilson-Ashworth, H.A.; Bell, J.D. Use of fluorescence to determine the effects of cholesterol on lipid behavior in sphingomyelin liposomes and erythrocyte membranes. J. Lipid Res. 2008, 49, 1202-1215. [CrossRef] [PubMed]

58. Armengol, E.; Domenech, O.; Fusté, E.; Pérez-Guillén, I.; Borrell, J.H.; Sierra, J.M.; Vinas, M. Efficacy of combinations of colistin with other antimicrobials involves membrane fluidity and efflux machinery. Infect. Drug Resist. 2019, 12, 2031-2038. [CrossRef] [PubMed]

59. Patiño-Márquez, I.A.; Manrique-Moreno, M.; Patiño-González, E.; Jemioła-Rzemińska, M.; Strzałka, K. Effect of antimicrobial peptides from Galleria mellonella on molecular models of Leishmania membrane. Thermotropic and fluorescence anisotropy study. J. Antibiot. (Tokyo) 2018, 71, 642-652. [CrossRef]

60. Lee, D.G.; Kim, P.I.; Park, Y.; Woo, E.R.; Choi, J.S.; Choi, C.H.; Hahm, K.S. Design of novel peptide analogs with potent fungicidal activity, based on PMAP-23 antimicrobial peptide isolated from porcine myeloid. Biochem. Biophys. Res. Commun. 2002, 293, 231-238. [CrossRef]

61. Jasniewski, J.; Cailliez-Grimal, C.; Younsi, M.; Millière, J.B.; Revol-Junelles, A.M. Fluorescence anisotropy analysis of the mechanism of action of mesenterocin 52A: Speculations on antimicrobial mechanism. Appl. Microbiol. Biotechnol. 2008, 81, 339-347. [CrossRef]

62. Jaehnig, F.; Vogel, H.; Best, L. Unifying description of the effect of membrane proteins on lipid order. Verification for the melittin/dimyristoylphosphatidylcholine system. Biochemistry 1982, 21, 6790-6798. [CrossRef]

63. Oren, Z.; Shai, Y. Mode of action of linear amphipathic $\alpha$-helical antimicrobial peptides. Biopolymers 1998, 47, 451-463. [CrossRef]

64. Niu, S.F.; Jin, Y.; Xu, X.; Qiao, Y.; Wu, Y.; Mao, Y.; Su, Y.Q.; Wang, J. Characterization of a novel piscidin-like antimicrobial peptide from Pseudosciaena crocea and its immune response to Cryptocaryon irritans. Fish Shellfish Immunol. 2013, 35, 513-524. [CrossRef] [PubMed]

65. Petersen, T.N.; Brunak, S.; Von Heijne, G.; Nielsen, H. SignalP 4.0: Discriminating signal peptides from transmembrane regions. Nat. Methods 2011, 8, 785-786. [CrossRef] [PubMed]

66. Greenfield, N.J. Using circular dichroism spectra to estimate protein secondary structure. Nat. Protoc. 2007, 1, 2876-2890. [CrossRef] [PubMed]

67. Ladokhin, A.S.; Jayasinghe, S.; White, S.H. How to measure and analyze tryptophan fluorescence in membranes properly, and why bother? Anal. Biochem. 2000, 285, 235-245. [CrossRef]

68. Rathinakumar, R.; Wimley, W.C. Biomolecular engineering by combinatorial design and high-throughput screening: Small, soluble peptides that permeabilize membranes. J. Am. Chem. Soc. 2008, 130, 9849-9858. [CrossRef]

69. Ladokhin, A.S. Fluorescence spectroscopy in thermodynamic and kinetic analysis of $\mathrm{pH}$-dependent membrane protein insertion. Methods Enzymol. 2009, 466, 19-42.

70. Fernández-Vidal, M.; White, S.H.; Ladokhin, A.S. Membrane partitioning: "classical" and "nonclassical" hydrophobic effects. J. Membr. Biol. 2011, 239, 5-14. [CrossRef]

71. Domadia, P.N.; Bhunia, A.; Ramamoorthy, A.; Bhattacharjya, S. Structure, interactions, and antibacterial activities of MSI-594 derived mutant peptide MSI-594F5A in lipopolysaccharide micelles: Role of the helical hairpin conformation in outer-membrane permeabilization. J. Am. Chem. Soc. 2010, 132, 18417-18428. [CrossRef]

72. Kim, J.Y.; Park, S.C.; Yoon, M.Y.; Hahm, K.S.; Park, Y. C-terminal amidation of PMAP-23: Translocation to the inner membrane of Gram-negative bacteria. Amino Acids 2011, 40, 183-195. [CrossRef] 
73. do Canto, A.M.T.M.; Robalo, J.R.; Santos, P.D.; Carvalho, A.J.P.; Ramalho, J.P.P.; Loura, L.M.S. Diphenylhexatriene membrane probes DPH and TMA-DPH: A comparative molecular dynamics simulation study. Biochim. Biophys. Acta Biomembr. 2016, 1858, 2647-2661. [CrossRef]

74. Belokoneva, O.S.; Villegas, E.; Corzo, G.; Dai, L.; Nakajima, T. The hemolytic activity of six arachnid cationic peptides is affected by the phosphatidylcholine-to-sphingomyelin ratio in lipid bilayers. Biochim. Biophys. Acta Biomembr. 2003, 1617, 22-30. [CrossRef] [PubMed]

(C) 2020 by the authors. Licensee MDPI, Basel, Switzerland. This article is an open access article distributed under the terms and conditions of the Creative Commons Attribution (CC BY) license (http://creativecommons.org/licenses/by/4.0/). 